Bull. Mater. Sci., Vol. 17, No. 6, Novembur 1994. pp. 1167-1179. (C) Printed in India.

\title{
Development of indigenous technology for production of titanium sponge by the Kroll process
}

\author{
CH R V S NAGESH, T S SITARAMAN, C S RAMACHANDRAN \\ and $R$ B SUBRAMANYAM \\ Defence Metallurgical Research Laboratory, Hyderabad 500258 , India
}

\begin{abstract}
Titanium has emerged as a major structural metal for a wide range of industrial applications due to its attractive engineering properties. India has a large and rich reserve base for this metal in the beach sands of the eastern and southern regions with well established production facilities for their separation into individual minerals. Research and Development activities for estahlishing the metal production technology have been underway in the country for over two decades. The Defence Metallurgical Research Laboratory, Hyderabad, has already demonstrated the metal production iechnology by the conventional Kroll process on $2000 \mathrm{~kg} / \mathrm{batch}$ scale and is now all set for demonstrating the same by the more advanced, energy efficient combined process route on $4000 \mathrm{~kg} / \mathrm{batch}$ scale. The paper reviews the $R \& D$ efforts undertaken so far in the ficld of metal extraction with emphasis on the current status of this developmental activity at DMRL.
\end{abstract}

Keywords. Titanium; Kroll process; combined process; magnesium: mono polar cell; multı polar cell.

\section{Introduction}

Titanium is the fourth most abundant structural metal after aluminium, magnesium and iron. Its unique engineering properties especially the high specific strength and outstanding corrosion resistance make it the most preferred metal for a variety of applications in a wide spectrum of industries such as the aerospace. power generation. chemical and petrochemical, paper and pulp. marine and ship building etc. Though started as an aerospace material, the metal has now reached the status of a common metal in the developed countries like Japan and the US owing 10 its impressive and useful properties. Titanium is also emerging as an ecofriendly metal due to its usage in the construction of antipollution equipment especially in the chemical and automobile industry.

In the earth's crust, titanium is mostly found in the form of oxide minerals viz. rutile $\left(\mathrm{TiO}_{2}\right)$ and ilmenite $\left(\mathrm{FeOTiO}_{2}\right)$. Due to the high thermodynamic stability of titanium oxides, attempts to prepare the metal directly from oxide have not been successful and the metal extraction through the chloride route is widely practised by the industry. Among various processes to prepare titanium metal from titanium tetrachloride, three processes viz. (i) the Hunter's sodium reduction, (ii) the Kroll's magnesium reduction and (iii) the fused salt electrolysis of $\mathrm{TiCl}_{4}$, gained industrial significance. Out of these the Kroll's process of reducing titanium tetrachloride with liquid magnesium has gained wider industrial acceptance because of its technical viability for production of sponge in larger, commercial size batches and the relative ease of recycling the magnesium chloride by-product to regenerate magnesium metal for reduction and chlorine for the production of $\mathrm{TiCl}_{4}$ from the oxide mineral 
concentrates. Thus, the Kroll process has emerged as the major metal extraction process for economic production of titanium sponge on industrial scale and currently over $97 \%$ of the world capacity is exclusively by this route. The Kroll sponge production technology involves the following process steps: (i) preparation of $\mathrm{TiCl}_{4}$ by chlorination of oxide concentrates, (ii) reduction of $\mathrm{TiCl}_{4}$ by magnesium, (iii) separation of $\mathrm{Mg} / \mathrm{MgCl}_{2}$ from the reaction mass and (iv) mechanical processing of sponge to a final size required for the subsequent ingot melting.

During the last two decades there have been many breakthroughs and innovations in the Kroll technology resulting in large scale production of the metal much more economically than ever before. While the development of fluidized bed chlorination revolutionized the tetrachloride production, the advent of combined process lead to production of superior quality sponge on larger size batches resulting in lower specific power consumption for metal production. The development of multipolar cell for magnesium electrolysis has also contributed in a significant way for the economic production of titanium sponge because of the reduced $\mathrm{MgCl}_{2}$ recycling costs.

India has more than one reason to go in for commercial production of the metal titanium. Annually, considerable amount of valuable foreign exchange is being spent on import of copper and nickel. The country has the opportunity to come out of this situation due to the fact that many copper and nickel alloy components can be replaced with titanium. Further, the country has a rich and large mineral base for titanium with our ilmenite and rutile reserves estimated at 140 and 8 million tonnes, respectively. Keeping in view the strategic nature of the metal (based on critical dependence of the Aerospace and Defence related industries on titanium), it is too risky to rely on sponge imports. Also, the country has all the production facilities starting from mineral beneficiation to the manufacture of titanium mill products except for sponge production.

\section{Development of metal production technology in the country}

Laboratory studies on $\mathrm{TiCl}_{4}$ and titanium sponge preparation by magnesium, sodium and fused salt electrolysis were initially carried out at BARC, Bombay in the 1960s (Sridhar Rao et al 1969; Ahluwalia et al 1973). Pilot plant investigations carried out at the Nuclear Fuel Complex, Hyderabad during 1970s on sodium reduction and magnesium reduction on $100 \mathrm{~kg}$ batches (Kulkarni et al 1980) lead to the important conclusion that the Kroll process is highly suitable for scaling up operations and the knowledge base generated will be adequate to design and engineer process equipment for much larger batch sizes.

\section{DMRL technology for $2000 \mathrm{~kg} / \mathrm{batch}$ sponge production}

In the year 1985, the Defence Metallurgical Research Laboratory, Hyderabad, commissioned a Technology Demonstration Plant for titanium sponge production on $2000 \mathrm{~kg}$ per batch size by the Kroll process. The DMRL facility is equipped to study and establish the process parameters for (i) $\mathrm{TiCl}_{4}$ purification by two-stage fractional distillation for the production of pure $\mathrm{TiCl}_{4}$ at a rate of $150 \mathrm{~kg} / \mathrm{h}$, (ii) magnesiothermic reduction of $\mathrm{TiCl}_{4}^{*}$ followed by vacuum distillation in two 
separate reactor assemblies to produce $2000 \mathrm{~kg}$ of titanium sponge per batch, and (iii) mechanical processing of sponge including sponge cake withdrawal from the reactor (crucible) and its size reduction operations (Sridhar Rao and Subramanyam 1985; Subramanyam and Sridhar Rao 1986). Realizing the importance of recycling the by-product magnesium chloride for the economic production of titanium sponge, DMRL has parallely progressed an $R \& D$ programme on the development of the fused-salt electrolytic process for regenerating magnesium and chlorine, in collaboration with the Central Electrochemical Research Institute, Karaikudi (CECRI).

Figure 1 depicts the DMRL flow sheet for titanium sponge production starting from raw titanium tetrachloride.

\section{Chloride purification}

A two-stage distillation scheme has been designed and set-up to separate (i) dissolved gases like $\mathrm{O}_{2}, \mathrm{~N}_{2}, \mathrm{Cl}_{2}, \mathrm{HCl}, \mathrm{COCl}_{2}, \mathrm{COS}$ etc, (ii) volatile impurities like $\mathrm{SiCl}_{4}$, $\mathrm{SnCl}_{4}, \mathrm{CCl}_{4}, \mathrm{~S}_{2} \mathrm{Cl}_{2}, \mathrm{CH}_{3} \mathrm{Cl}$ etc and (iii) other high boiling impurities such as $\mathrm{FeCl}_{3}$, $\mathrm{NbCl}_{3}, \mathrm{TaCl}_{5}, \mathrm{C}_{6} \mathrm{Cl}_{6}, \mathrm{TiOCl}_{2}$ etc. The distillation columns are equipped with suitable heaters, sealless pumps, valves and instruments like level transmitters, diaphragm sealed pressure gauges, flow transmitters, etc. All the field instruments are interfaced with the process computer (DCS) and all the heaters are also connected to DCS through thyristor controllers.

The raw tetrachloride is purified in the first distillation column to separate dissolved gases and all low boiling impurities such as $\mathrm{SiCl}_{4}, \mathrm{SnCl}_{4}$ etc as per the typical operation conditions given in table 1 and distilled through the second stripper column to obtain pure $\mathrm{TiCl}_{4}$ suitable for reduction.

\section{Metal production $-2000 \mathrm{~kg}$ batches}

The crucial step of sponge production is the reduction process operation and it involves careful control of process parameters viz. reaction temperature, pressure and $\mathrm{TiCl}_{4}$ admission rate. Also, the scheme of $\mathrm{MgCl}_{2}$ removal from the reactor during reaction, quantity of excess magnesium used and control of generation of titanium lower chlorides are other important aspects which can significantly influence the process operation. The quality of sponge is dependent on the reduction process parameters as well as subsequent vacuum distillation process parameters (temperature and duration) even if the input materials $\left(\mathrm{TiCl}_{4}\right.$ and $\mathrm{Mg}$ ) are of high quality. In the DMRL facility 24 experimental production runs have been carried out and various process parameters of sponge production have been thoroughly studied (Subramanyam et al 1990). Typical process parameters found optimal are presented in table 2. Figure 2 is a $2000 \mathrm{~kg}$ sponge cake produced in one of the experimental runs. Table 3 presents typical analysis of titanium sponge produced in the facility.

\section{Development of $4000 \mathrm{~kg}$ combined process technology}

Combining the reduction and vacuum distillation processes to confine the two operations to a single station operation is a recent state-of-the-art technology and 
is now widely used for large scale production of titanium sponge more economically. Decreased power consumption, increased equipment productivity, reduced labour requirement and increased quality of the product are the main advantages claimed by the combined process (Ikeshima 1985: Noda 1988: Ke and Huijuan 1989). In

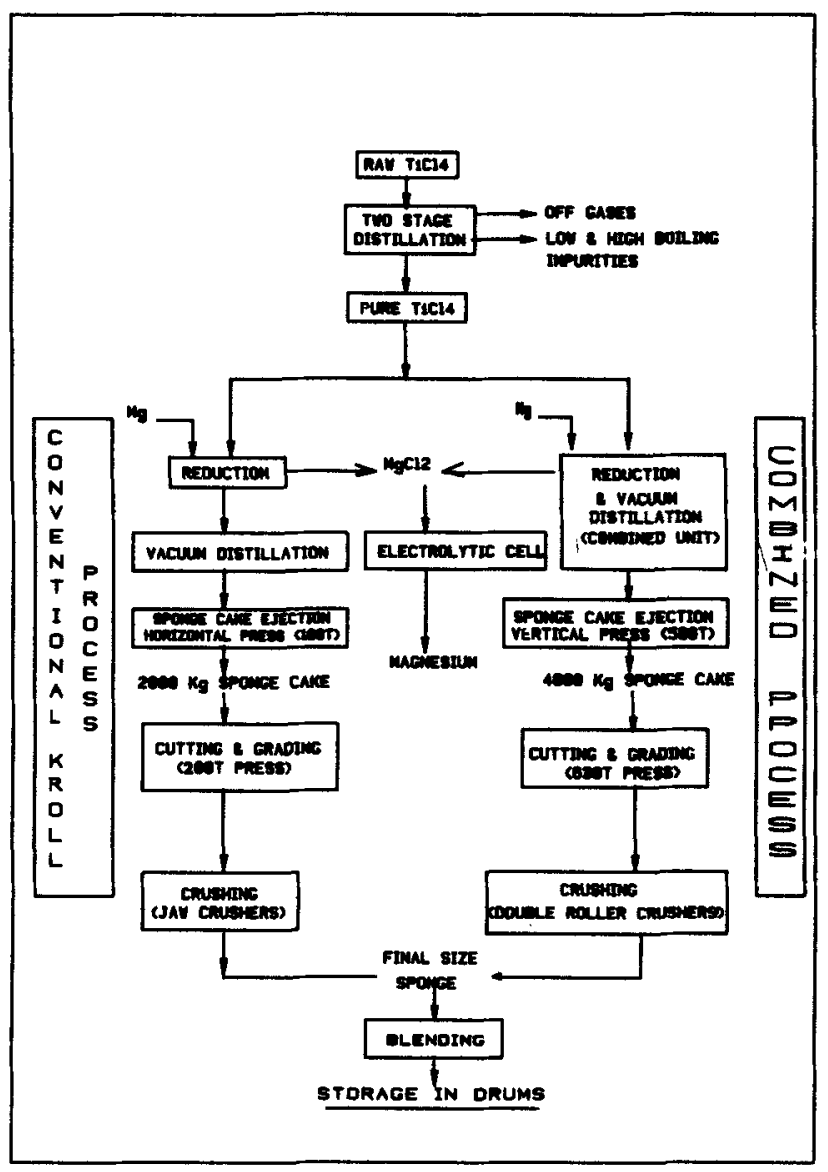

Figure 1. DMRL flow sheet for asc demonstration of titanium sponge production technology.

Table 1. Typical operating conditions of the distillation column.

\begin{tabular}{ll}
\hline Feed rate & $160 \mathrm{~kg} / \mathrm{h}$ \\
Distillate rate & $5 \mathrm{~kg} / \mathrm{h}$ \\
Reflux rate & $40 \mathrm{~kg} / \mathrm{h}$ \\
Botiom (product) rate & $150-155 \mathrm{~kg} / \mathrm{h}$ \\
Reflux ralio & $8: 1$ \\
Bottom temperature & $138 \cdot 1^{\circ} \mathrm{C}$ \\
Top temperature & $136 \cdot 5^{\circ} \mathrm{C}$ \\
Column pressure & $1-2 \mathrm{psig}$ \\
Sn level in bottom fraction & $20-25 \mathrm{ppm}$ \\
Sn level in top fraction & $200-250 \mathrm{ppm}$ \\
\hline
\end{tabular}


Table 2. Typical process parameters $-2000 \mathrm{~kg} / \mathrm{batch}$.

\begin{tabular}{ll}
\hline Reduction & \\
Excess magnesium & $30-40 \%$ \\
Temperature & $830-860^{\circ} \mathrm{C}$ \\
Reaction time & 24 to $30 \mathrm{~h}$ \\
TiCl4 feed rate & $300 \mathrm{~kg} / \mathrm{h}$ (max) \\
No. of tappings of $\mathrm{MgCl}_{2}$ & $12-16$ \\
Vacuum distillation & \\
Temperature & \\
$300^{\circ} \mathrm{C}$ & Soak time \\
$700^{\circ} \mathrm{C}$ & $6 \mathrm{~h}$ \\
$975^{\circ} \mathrm{C}$ & $8-10 \mathrm{~h}$ \\
Ultimate vacuum & $40-45 \mathrm{~h}$ \\
\hline
\end{tabular}

Table 3. Typical quality analysis of titanium sponge cake.

\begin{tabular}{lccccc}
\hline & \multicolumn{4}{c}{ Analysis (wt \%) } & Hardness \\
\cline { 2 - 5 } Location & $\mathrm{O}_{2}$ & $\mathrm{~N}_{2}$ & $\mathrm{C}$ & $\mathrm{Fe}$ & $(\mathrm{BHN})$ \\
\hline Centre & 0.0866 & 0.0012 & 0.0031 & 0.0140 & 90 \\
Side & 0.0878 & 0.0041 & 0.0226 & 0.0940 & 153 \\
Bottom & 0.1300 & 0.2000 & 0.0170 & 0.3000 & 213 \\
\hline
\end{tabular}

the combined process, after the reduction operation the reaction mass is immediately subjected to vacuum distillation without involving intermediate cooling, opening of the reactor, reloading of the batch into the vacuum distillation unit and reheating of the mass. However, the crux of the technology lies in the design of the process equipment especially the heated interconnecting pipe (between the process reactor and the condenser reactor), the high temperature, high vacuum isolation valve and the top transfer system for tapping out periodically the by-product liquid magnesium chloride from the reactor.

Based on the experience gained in the operation of the $2,000 \mathrm{~kg} / \mathrm{batch}$ equipment, DMRL is currently involved in the task of developing the combined process technology on $4000 \mathrm{~kg} / \mathrm{batch}$ scale. Design of equipment and other related systems for this larger unit has been carried out in association with MECON and IGCAR for demonstrating this latest technology for its subsequent commercial implementation. All the equipment have now been installed and the reactor assembly is being subjected to pre-process testing.

Salient features (figure 1) of the DMRL combined process technology include the following: (i) operation of reduction and vacuum distillation processes using a single double purpose $480 \mathrm{~kW}$ pit type electric resistance furnace, (ii) a $150 \mathrm{~mm}$ dia. stainless steel interconnecting pipe encircled by specially designed electric heaters, with an isolation valve, to combine the two stainless steel reactors positioned side by side, (iii) a valveless top transfer system for tapping the by-product liquid magnesium chloride from the reactor during the reduction stage into a specially designed ladle by the application of pressure/vacuum, (iv) an insulated ladle that acts as a receptacle for liquid $\mathrm{MgCl}_{2}$ which is essentially needed in an integrated plant for transferring the salt from the reactor to a fused salt electrolytic cell for 


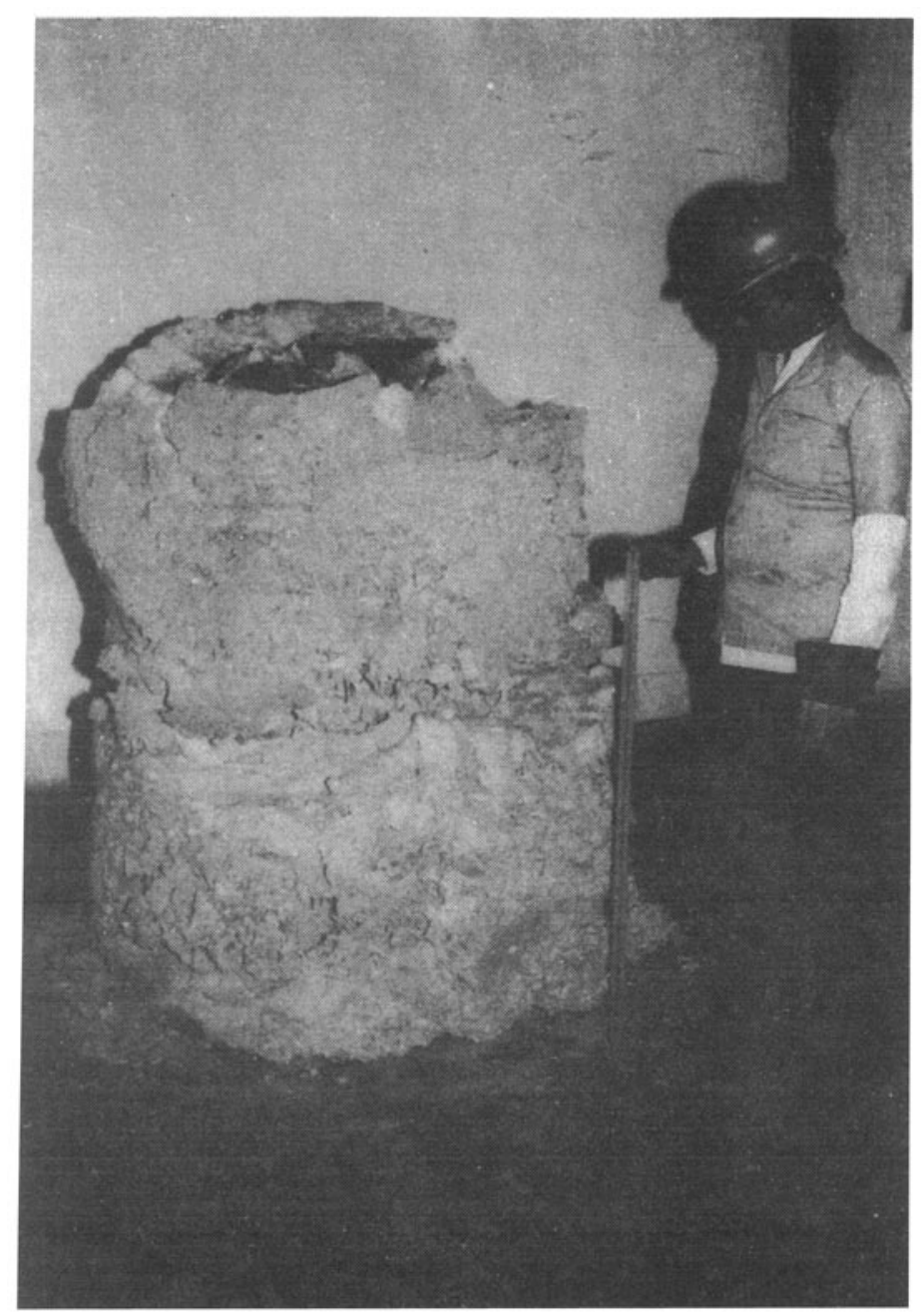

Figure 2. $2000 \mathrm{~kg}$ titanium sponge cake produced at DMRL.

the generation of magnesium and chlorine for recycling, (v) a sophisticated sponge cake ejection system and mechanical processing and comminution system and (vi) computer based instrumentation and process control of various process parameters.

\section{Process equipment}

\subsection{Reactor assembly}

Figure 3 is a schematic of the combined process equipment installed at DMRL. It comprises a set of two identical stainless steel reactors $(1.5 \mathrm{~m}$ dia and $5 \mathrm{~m}$ high) coupled by an interconnecting pipe with a specially designed high temperature, high vacuum isolation valve. A $480 \mathrm{~kW}$ pit type electric resistance furnace provides 


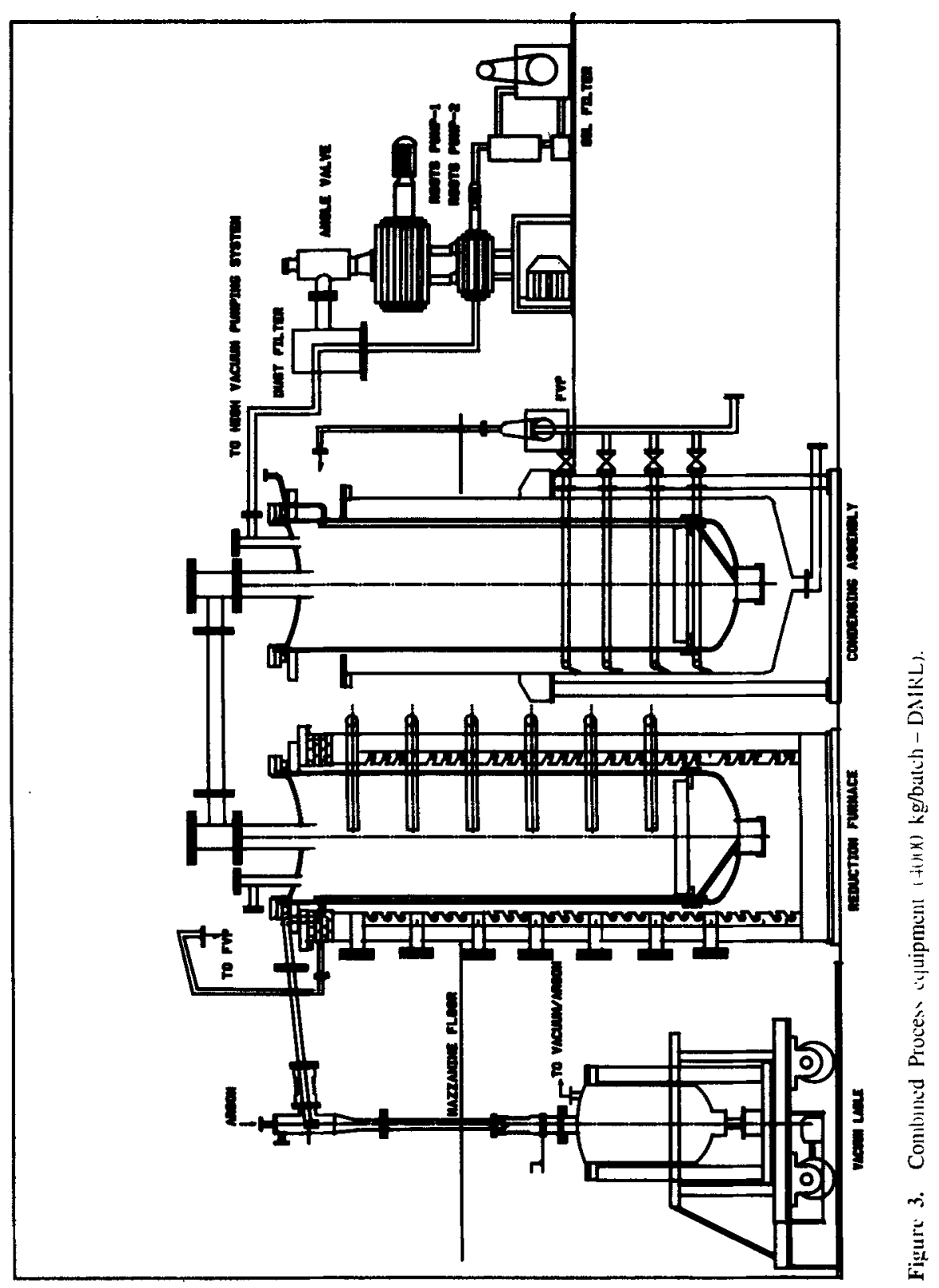


the heat requirements for reduction and vacuum distillation operations. A condenser station with elaborate cooling arrangement will be in operation during the vacuum distillation process for receiving and condensing the excess magnesium and residual magnesium chloride in the second reactor.

\section{2 $\mathrm{MgCl} 2$ top transfer system}

Figure 4 is a schematic of the top transfer system for the periodic withdrawal of molten $\mathrm{MgCl}_{2}$ from the reactor. It comprises a semi-circular stainless steel pipe welded all along the height of the inner wall of the reactor through which molten salt can flow upwards from the bottom of the reactor to outside. At the exit point the liquid is directed through an inclined stainless steel pipe terminating in a surge vessel the bottom of which is connected to a vacuum ladle through a steel pipe. Tapping of $\mathrm{MgCl}_{2}$ is achieved either by pressurization of the reactor or by applying vacuum on the ladle or by both these techniques if the situation so warrants. When tapping is not in progress the surge vessel is closed and a back pressure of argon is maintained to contain the by-product within the furnace zone of the reactor so as to eliminate the possibility of $\mathrm{MgCl}_{2}$ rising into the cold zone of the tapping pipe.

\subsection{Ladle}

As shown in figure 4 the ladle is a cylindrical carbon steel crucible placed inside a larger cylindrical vessel with insulation in between. Necessary provisions for evacuation and pressurization for receiving the by-product and for teeming the same into trays have been made. Molten magnesium chloride enters into the ladle through a nozzle fitted to the top closure, which is in turn connected to the surge vessel through a stainless steel bellow. The ladle rests on three load cells so as to measure the quantity of salt received by it in a given tapping. In addition to load cells a level indicator which generates an electric signal to stop further flow of magnesium chloride automatically when the required quantity is tapped is also provided to ensure correct amount of tapping.

The ladle chamber is completely insulated such that molten material can be retained without solidification for about $3 \mathrm{~h}$. An LPG burner initially heats up the chamber. The ladle can be moved on rails so as to take it to the salt bay for teeming into trays by pressure transfer. In an integrated Titanium Sponge Plant the molten magnesium chloride can be transferred directly into the electrolysis cells or a holding furnace.

As a prelude to the process operations, the top transfer system was subjected to a hot trial run. About $2000 \mathrm{~kg}$ of magnesium chloride was taken into the reactor, heated to a temperature of $800^{\circ} \mathrm{C}$ and transferred into ladle by applying pressure. The pressure requirement mainly depends on the liquid level inside the reactor and the desired rate of tapping. Temperature and pressure control, maintenance of slightly higher back pressure in the tapping line (as compared to the reactor inside pressure when tapping is not in progress), and automatic tapping of $\mathrm{MgCl}_{2}$ using DCS have all been successfully demonstrated. The details of the top tapping experiment are given in table 4. 


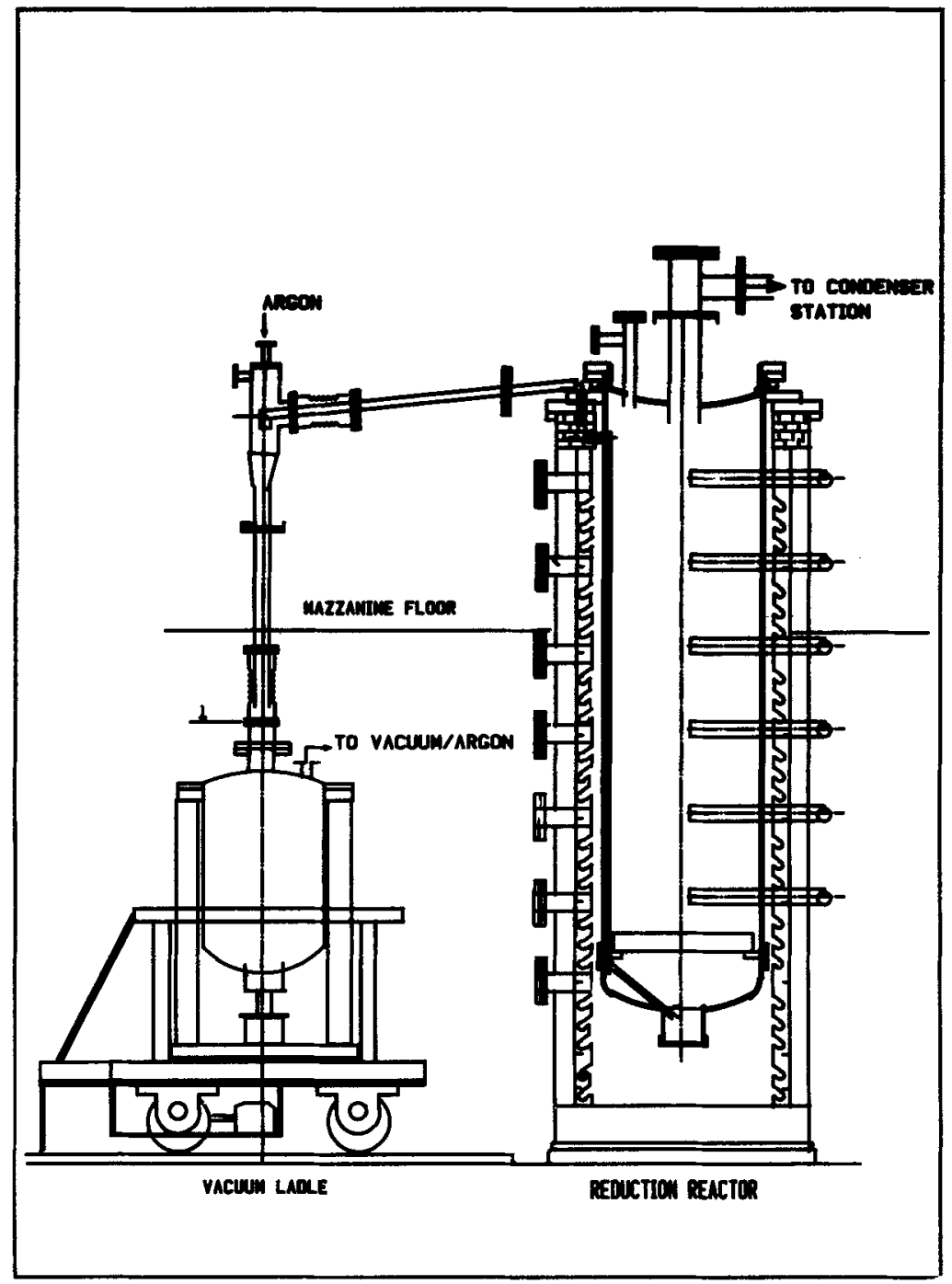

Figurc 4. Top transfier y isill for magnesium chloride.

\subsection{Process computer}

A 16 loop Distributed Control System has been installed and put into operation for automatic control of the various process parameters of $\mathrm{TiCl}_{4}$ purification and the combined unit. The DCS is also used for monitoring the process operations and logging the process data.

The process computer (DCS) with 16 main control loops, 16 auxiliary control loops and 512 digital I/Os is capable of handling 60 high level analog inputs directly connected to the system. Also 248 low level analog signals are connected to a serial port (RS-422 link) through an Analog Signal Multiplexer (ASM). The automatic control is accomplished with feed back on all process operations connected 
Table 4. Details of experiment on top transfer of $\mathrm{MgCl}_{2}$.

\begin{tabular}{lccc}
\hline Tap No. & $\begin{array}{c}\text { Reactor pressure } \\
\text { (psig) }\end{array}$ & $\begin{array}{c}\text { Duration } \\
(\mathrm{sec})\end{array}$ & $\begin{array}{c}\text { Qty. of } \mathrm{MgCl}_{2} \text { tapped } \\
(\mathrm{kg})\end{array}$ \\
\hline 1 & $8-9 \cdot 6$ & 50 & 345 \\
2 & $8 \cdot 2-9.9$ & 65 & 460 \\
3 & $8 \cdot 5-10.1$ & 90 & 633 \\
4 & $8 \cdot 5-11.1$ & 70 & 642 \\
\hline
\end{tabular}

to the DCS. The configuration and the user friendly software with complete failure feed back analysis was entirely developed in-house. On execution of some data acquisition program, the process computer provides a variety of process data which can be recorded using a printer at any selectable time interval.

\subsection{High vacuum pumping system}

The vacuum pumping system for carrying out vacuum distillation mainly consists of two high capacity roots pumps and an oil rotary vacuum pump connected in series with necessary valves and interlocks. A cryogenic cyclone separator and a cryogenic circulating type oil wet filter both operating at $-10^{\circ} \mathrm{C}$ are installed ahead of the roots pumps for trapping all condensable vapours and carry over solid particles. The system is operated through a remotely located control panel with necessary interlocks, safety features and audio-visual alarms to indicate any malfunctions.

\subsection{Sponge cake ejection press}

A $500 \mathrm{~T}$ hydraulic vertical press (figure 5) is installed for ejecting the sponge cake from the reactor. With the help of a set of spacers the ram pushes the sponge cake into a steel container mounted vertically over the retort. The container is provided with necessary nozzles for evacuating and back filling with argon before ejecting the cake.

\section{$7.7630 \mathrm{~T}$ guillotine press}

First breakdown of the sponge cake will be carried out on a specially designed $630 \mathrm{~T}$ hydraulic guillotine press. The sponge cake is kept on the moving shuttle of the press and is supported by a set of $\mathrm{V}$ blocks. A long sharp edged hardened steel tool is used for skinning out the outer impurity rich layers of the cake as well as for cutting the sponge cake into smaller lumps of about $150 \mathrm{~mm}$ size. At this stage of operation, sponge is also graded into different fractions. The press has been commissioned and crushing and grading of sponge cakes of $2000 \mathrm{~kg}$ has been satisfactorily demonstrated.

\subsection{Facilities for crushing and blending}

A 200 T vertical press with a steel cutting tool is employed for cutting bigger 


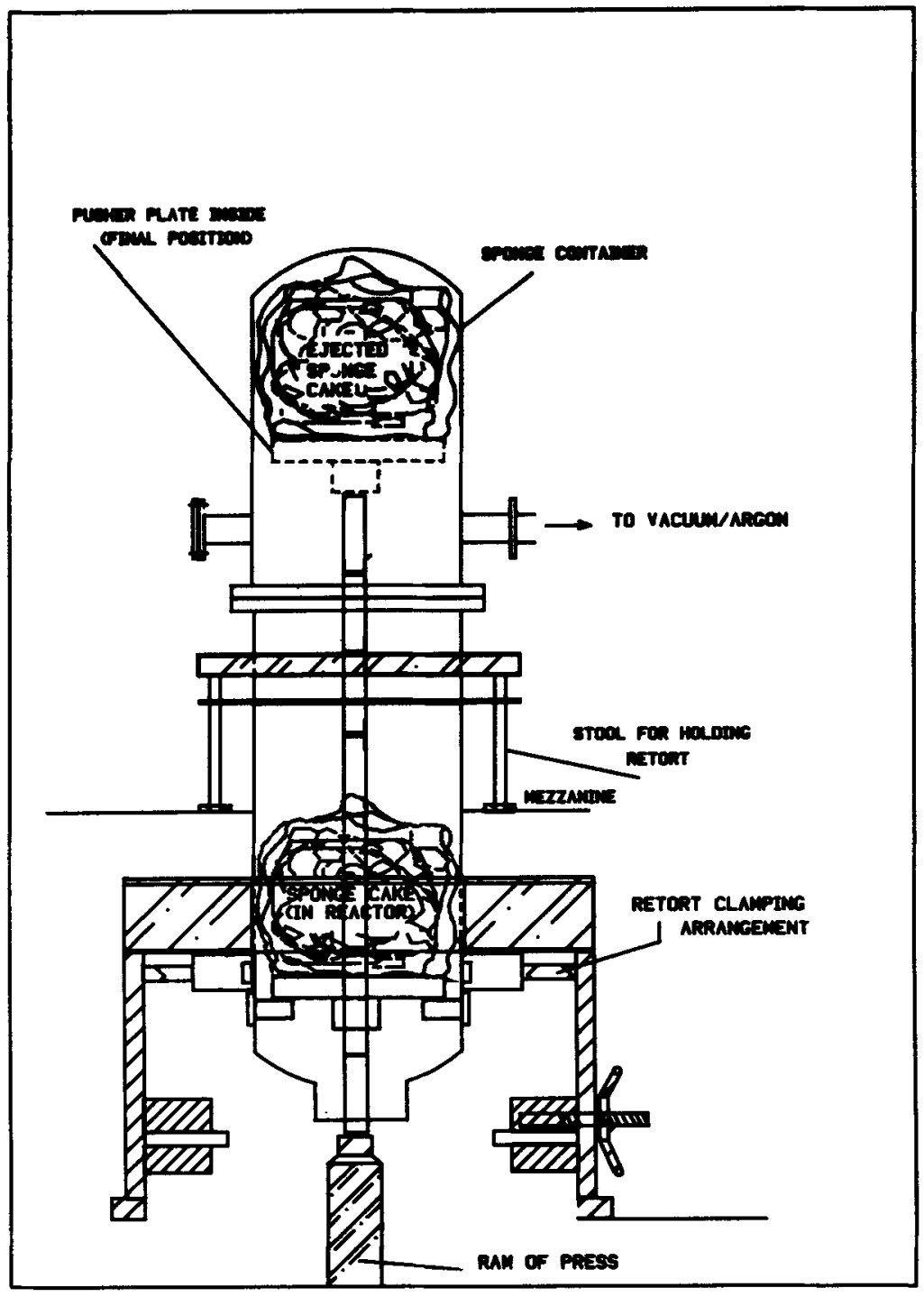

Figure 5. Gencral arrangement of $500 \mathrm{~T}$ press with retort and sponge container.

sponge lumps to a size of about $150 \mathrm{~mm}$ which will then be subjected to primary crushing in a toothed type double roll crusher to a size of $75 \mathrm{~mm}$. Secondary crushing will also be done in a second toothed type double roll crusher to a final size of -25 to $+2 \mathrm{~mm}$. A double cone blender of $1 \mathrm{~T}$ capacity is used for blending of sponge lumps to make a 'lot' of uniform quality.

Currently primary and secondary crushing of sponge is being carried out in jaw crushers. Use of jaw crushers for this purpose, however, has not been found to be efficient calling for repeated recycling. Compaction/flattening of sponge with rise in temperature is yet another problem frequently faced with jaw crushers. In the light of the experience gained and based on satisfactory trails conducted on roll crushers, two numbers of double roll toothed type roll crushers are under procurement. 


\section{Development of magnesium chloride technology}

With a view to recycling the by-product anhydrous magnesium chloride, a $30 \mathrm{kA}$ mono-polar modular type cell with 12 modules of $2.5 \mathrm{kA}$ each has been designed, commissioned and successfully operating over prolonged periods (Nataraj Sekhar et al 1987). Based on this experience, a $7 \mathrm{kA}, 2$-module cell with 5 bipoles in each module has been designed and fabricated. Commissioning trails of the same are in progress.

\section{Summary}

The Technology Development Centre for titanium sponge production established at DMRL is a unique facility specifically designed to develop the Kroll process of titanium sponge production on a commercially viable scale. The intention is to develop and demonstrate the technology to prospective entrepreneurs on a full size unit so as to avoid the necessity of further scale up and its associated uncertainties. Commercial plants of any capacity can be set up by the installation of a plurality of the type of equipment set up and demonstrated at DMRL.

The above objective in respect of $2000 \mathrm{~kg}$ batch by the conventional two-step Kroll process has already been achieved. Substantial progress has also been made in the establishment and commissioning of the $4000 \mathrm{~kg}$ batch equipment of the combined process route. Top tapping of magnesium chloride into the vacuum ladle and teeming of the tapped out magnesium chloride from the ladle into trays using computer controlled instrumentation (a crucial and critical operation in sponge production by the combined process route) has recently been successfully demonstrated. Controlled cutting and grading of sponge cake on the $630 \mathrm{~T}$ capacity hydraulic guillotine press with specially designed tooling has also been demonstrated on a $2000 \mathrm{~kg}$ sponge cake. From the progress achieved, it is expected that the technology for titanium sponge production in $4000 \mathrm{~kg}$ batches by the combined process route will be demonstrated and optimized shortly. Parallely DMRL has worked out the cost estimates for establishing a 1000 TPY Integrated Titanium Sponge Plant with a matching Magnesium Plant for recycling by-product magnesium chloride based on the equipment designs evolved as described above.

\section{Acknowledgements}

Technology Development for large scale titanium sponge production is a multi-disciplinary activity and active contributions of various agencies and individuals have been instrumental in the implementation of this programme.

The initiatives taken by $\operatorname{Dr}$ V S Arunachalam, the then Secretary, Department of Defence Research and Development and Dr P K Iyengar, the then Secretary, Department of Atomic Energy, have been primarily responsible for this sponsored research project funded by the Department of Atomic Energy. The authors wish to place on record their grateful thanks to both of them.

The design of the Kroll reactors and associated equipment have been evolved after extensive discussions with Shri S C Chetal and his team of Engineers from the Indira Gandhi Centre for Atomic Research, Kalpakkam (IGCAR) and Shri 
M Seenaiah, Nuclear Fuel Complex (NFC), Hyderabad. Stage-wise inspection of the reactor vessels during fabrication has been carried out by Shri R Madeswaran, IGCAR, strictly according to ASME Code for pressure vessels. Smt Uma Seshadri and her colleagues at IGCAR, Shri D Sreedhar, NFC and Shri G V S Brahmendra Kumar, DMRL were responsible for the design, erection, testing and commissioning of the computer based DDC system for the chloride purification and the Combined Process equipment. Field fabrication and commissioning of the various auxiliary units and electrics have been carried out by Messrs $S$ A Jesudasan, R Guruprasad, S N Narendra Babu and M Kirtania, DMRL and Mr Johnson D'Souza, NFC. The outstanding contributions and the dedicated efforts put in by all the above Scientists and Engineers from IGCAR, NFC and DMRL are gratefully acknowledged.

Prof. C V Sundaram, National Institute of Advanced Studies, Bangalore and Prof. P Rama Rao, Secretary, Department of Science and Technology, New Delhi, have shown keen interest in this project and provided constant support and encouragement. The authors wish to place on record their grateful thanks to both of them. Shri S L N Acharyulu, Director, DMRL, has provided unstinted support at all stages of the project for which the authors are deeply indebted.

\section{References}

Ahluwalia H S et al 1973 BARC Report No. 683, Bombay

Ikeshima T 1985 Titanium science and technology (eds) G Lutjering, $\mathrm{U}$ Zwicker and W Bunk (FRG: DGM Press) Vol. 1, p. 5

Ke W and Huijuan M 1989 in W-Ti-Re-Sb 88, Proc. of the first int. conf. on the metallurgy and materials science of tungsten, titanium rare earths and antimony, (ed.) Fu Chongyue (Beijing: Pergamon-CNPIEC Joint Venture) Vol. 1, pp. 299-305

Kulkarni A P et al 1980 in Titanium 80 science and technology (eds) H Kimura and O Izuni (Warrendale, Pa: Met. Soc. AIME) p. 1927

Nataraj Sekhar K et al 1987 B. Electrochem. 3127

Noda T 1988 AMIE annual meeting, Phoenix, p. 759

Sridhar Rao Ch and Subramanyam R B 1985 Light metals: Science and technology, Proc. of int. symposium (Switzerland: Trans Tech Publications) pp. 171-184

Sridhar Rao Ch, Kulkarni A P and Sundaram C V 1969 Trans. IIM 2210

Subramanyam R B and Sridhar Rao Ch 1986 Defence Sci. J. 36105

Subramanyam R B et al 1990 High Temp. Mater. Process 9195 